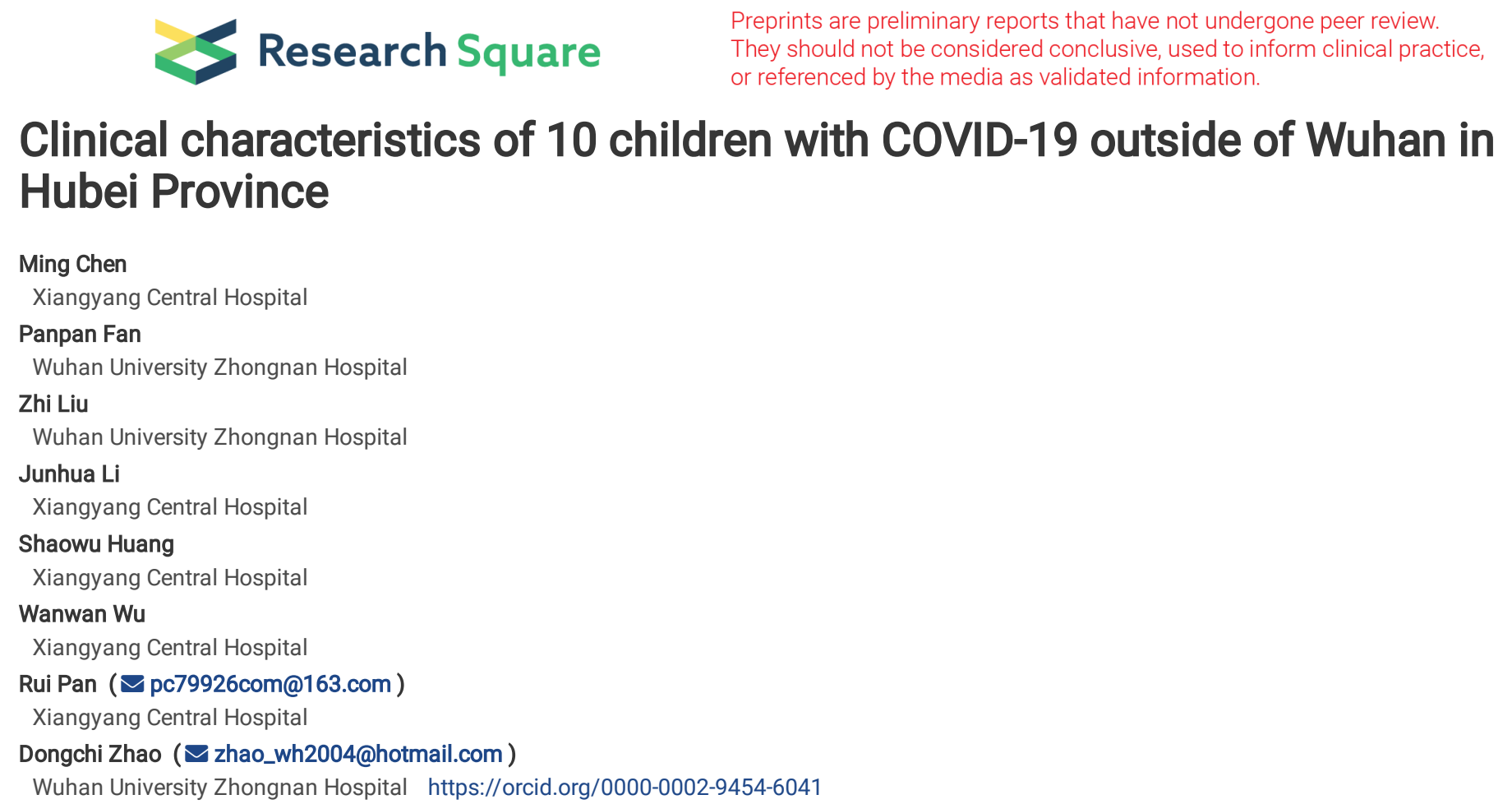

\section{Clinical characteristics of 10 children with COVID-19 outside of Wuhan in Hubei Province}




\section{Abstract}

Background $\triangle A$ An outbreak of coronavirus disease 2019 (COVID-19) caused by the Severe Acute Respiratory Syndrome Coronavirus 2 (SARS-CoV-2) began in Wuhan, Hubei Province, China in December 2019. This study aims to report the clinical characteristics of children COVID-19 in Xiangyang, a city outside of Wuhan within Hubei Province.

Methods $\triangle$ We retrospectively investigated the clinical manifestations, Chest CT imaging, and laboratory characteristics of confirmed cases of children with COVID-19 with WHO interim guidance in Xiangyang Central Hospital from Feb 1 to Mar 10, 2020. 10 children cases were confirmed by real-time RT-PCR and were analyzed for epidemiological, demographic, clinical, radiological features and laboratory data. Outcomes were followed up until Mar 10, 2020.

Results $₫ 6$ cases $(60 \%)$ had never been to Wuhan but closely contacted with family members with confirmed COVID- 19 , and 4 cases ( $40 \%$ ) had made short term trips to Wuhan alone without familial clustering. The most common symptoms were cough (50\%) followed by fever (40\%), 4 cases ( $40 \%)$ showed asymptomatic characteristics including 2 cases (20\%) with abnormal chest computed tomograms (CT) image. 9 cases (90\%) were mild type, only 1 case (10\%) was moderate type, none of them progressed in severe or critical disease. $4(40 \%)$ cases showed leucopenia but none lymphopenia. Abnormalities on chest CT were detected among 8 cases (80\%), 2 of 4 cases without obvious symptoms had abnormal chest CT.

Conclusions: Children's infection is mainly caused by family clusters. No transmission to other individuals from children was found in our observation. The clinical manifestations in children with COVID-19 are non-specific with milder symptoms and good outcomes.

\section{Background}

Since late December 2019, an outbreak of coronavirus disease 2019 (COVID-19)[1] was reported in Wuhan, China, which has subsequently spread worldwide[2]. As of March 10, 2020, there were 80,924 reported cases in China and 32,778 cases out of China, including more than 800 children cases. There have been 4012 deaths worldwide[3], and no deaths have been reported in children cases.

Given the rapid spread of COVID-19, we determined that an updated analysis of cases in children in another city around Wuhan within Hubei province, which might help identify the defining transmission dynamics, clinical characteristics, and severity of the disease in children. Here, we describe the results of the clinical characteristics of COVID-19 in 10 children cases in Xiangyang, China.

\section{Methods}

\section{Patients and data collection}

All enrolled 10 pediatric patients identified to be viral nucleic acid-detection for the severe acute respiratory syndrome coronavirus 2 (SARS-CoV-2), who were referred to the Xiangyang Central Hospital from Feb 1 to Mar 10, 2020, were retrospectively analyzed. The clinical outcomes (discharges, mortality and length of stay) were monitored up to Mar 10,2020, the final date of follow-up. Data regarding epidemiological, clinical, laboratory, and radiological characteristics, as well as the treatment and outcomes, were obtained with collection forms from electronic medical records. Data collection of laboratory results were defined using the first-time examination at admission (within $24 \mathrm{~h}$ after admission).

\section{Diagnostic criteria}

According to "Diagnosis and treatment protocol for COVID-19 (Seventh Trial Edition)" by the National Health Commission of the People's Republic of China, cases in this study were defined as individuals with epidemiological history and two or more persistent clinical manifestations followed by pathogenic evidence[4]. The details are as follows:

1. Epidemiological history: (1) There were tourism or residence histories of Wuhan or its surrounding areas or other communities with confirmed cases within 14 days before onset; (2) There were contacts with confirmed cases of COVID-19 within 14 days before onset; (3) There were contacts with patients with fever or respiratory symptoms from Wuhan and surrounding areas or other communities with confirmed cases within 14 days before onset; (4) Aggregation: Two or more cases with fever and/or respiratory symptoms were found in an enclosed environment (such as a family house, an office, a class, etc.) within 14 days.

2. Clinical manifestations: (1) Fever and/or respiratory symptoms; (2) Chest imaging indicated multiple mottling and interstitial changes during the early stage, mostly at the periphery of the lung, which subsequently developed into bilateral ground-glass opacity, infiltrates shadows and even lung consolidation. Pleural effusion was rarely seen; (3) Normal or decreased total white blood cell count and lymphocyte count in the early stages of the disease.

3. Clinical classification: In brief, the mild type has no signs of pneumonia on chest imaging. The moderate type includes fever and respiratory symptoms, and signs of pneumonia on radiologic assessment. The severe type meets any of the following criteria: (1) shortness of breath, RR $\geq 30$ times/min; (2) oxygen saturation $\leq 92 \%$ at rest; (3) assisted breathing (groaning, alar agitation, sunken sign), cyanosis, intermittent apnea (4) drowsiness or convulsion; (5) feed refusal or feeding difficulties, with dehydration. The critical type meets any of the following criteria: (1) respiratory failure, need mechanical ventilation; (2) shock; (3) any other organ failure occurs, needs to be transferred to the intensive care unit (ICU).

\section{The qRT-PCR assay for SARS-CoV-2}

Quantitative real-time PCR (qRT-PCR) was performed to detect viral nucleic acid of nasopharyngeal swab samples. Nasopharyngeal swabs were detected immediately after admission, and COVID-19 was identified by qRT-PCR assay using a 2019-nCoV nucleic acid detection kit according to the manufacturer's protocol (Bioperfectus technologies, Jiangsu, China ). The qRT-PCR assay was performed under the following conditions: incubation at $50^{\circ} \mathrm{C}$ for 30 minutes 
and $95^{\circ} \mathrm{C}$ for 5 minutes, 45 cycles of denaturation at $95^{\circ} \mathrm{Cfor} 10$ seconds, and extending and collecting fluorescence signal at $55^{\circ} \mathrm{C}$ for 40 seconds. A cycle threshold value (Ct-value) less than 35 was defined as a positive test result, and a Ct-value of 38 or more was defined as a negative test. A medium load, defined as a Ct-value from 35 to less than 38 , required confirmation by retesting.

\section{Results}

The 10 cases were identified between Jan 31, 2020, and Feb 18, 2020. 7 patients were female. They range in age from 2 to 15 years old(Table 1 ). All the 10 pediatric patients were native residents in Xiangyang about 350 kilometers away from Wuhan.

\section{The disease timeline of each child}

Of the 10 cases, 6 cases (Case1-Case6) had never been to Wuhan but closely contacted with family members with confirmed COVID-19, the incubation period of each child after the first confirmed COVID-19 in the family developed symptoms were 4-13 days (Fig.1). Four cases (Case7-Case10) had made short term trips to Wuhan or visited relatives with confirmed COVID-19 alone, and they started to show symptoms 3-10 days after they went back home.

Four children had been living with their families throughout the whole course of the disease, including elderly grandparents, but no familial members else had been infected (confirmed by nucleic acid test and chest CT) (Table 1). Admittedly, the 6 cases with family cluster demonstrated adult-to-child transmission, however, the other 4 children did not show the viral transmission to long-time closely contacted adult households including elderly people.

\section{Clinical characteristics}

In terms of clinical classification, 9 cases were mild (5) or asymptomatic (4), only 1 case developed moderate signs, none of them progressed in severe critical illness. The most common symptoms were cough (5,50\%) and fever (4,40\%) respectively. Myalgia, fatigue, headache, diarrhea, or other symptoms had not been found in the 10 cases. Among the 6 cases who had symptoms, 4 cases got rid of the symptoms within 1 week, the duration of symptoms lasted for $2-15$ days.

\section{Laboratory results and radiologic findings}

On admission, the blood routine test of 4 patients $(40 \%)$ showed leucopenia (Leucocytes count $<5 \times 10^{9} / \mathrm{L}$ ), none had lymphopenia (lymphocyte count $\left.<1.1 \times 10^{9} / \mathrm{L}\right)$. Paradoxically, 8 cases $(80 \%)$ showed relatively higher lymphocyte percent, which was not consistent with previous reports. All the 10 cases had normal serum levels of procalcitonin (PCT, $<0.5 \mathrm{ng} / \mathrm{mL}$ ), and only 1 case had elevated C-reactive protein (CRP) (Table 2). None of the 10 cases showed abnormal liver and kidney function and electrolytes (date not shown). 7 cases (70\%) had more than 4 times of nucleic acid tests. The ranges for virus nucleic acid to turn negative were 14 days (5-22 days).

Abnormalities on chest CT sign were detected in 8 cases (80\%), mostly manifested as single or multiple localized high-density shadows (4/8), and unilateral ground-glass opacity $(3 / 8,37.5 \%)$, except for 2 cases who showed asymptomatic characteristics. It should be noted that 2 of 4 cases without obvious symptoms also had localized high-density shadow or ground-glass opacity imaging. Representative radiologic findings in two cases were provided in Figure 2.

\section{Treatment and clinical outcomes}

At the very beginning, there were neither effective antiviral drugs nor any experience in treatment for pediatric patients with COVID-19. Treatment for pediatric patients was based on the experience of adult treatment. All cases received antiviral treatment, and only one was given empirical antibiotic treatment. No one received systematic corticosteroid or immunoglobulin treatment. Besides, 6 cases were given traditional Chinese medicine (Lianhua Qingwen Capsule) (Table 2).

All cases were discharged without any complication when they met the discharge standard: body temperature returned to normal for more than 3 days, respiratory symptoms improved significantly, and the respiratory pathogenic nucleic acid test was negative for two consecutive times (sampling interval at least 1 day). The median times of hospital stay were 18 days (7-26 days). The prolonged hospital stay was mainly due to prolonged positive nucleic acid tests.

\section{Discussion}

The current outbreak of COVID-19, which has affected more than 100,000 people worldwide and continues to grow rapidly by now, poses a huge potential threat to children. In this report, we summarized the pediatric characteristics with COVID-19.

Based on our observations and current scattered case reports on children[5-13] and adults[14-18], the clinical manifestations of children patients were relatively mild, which was similar to SARS. A few reports about children with SARS showed that pediatric patients had relatively mild symptoms and were less likely to be admitted to an intensive care unit, receive supplemental oxygen, or be treated with methylprednisolone [16, 19]. Similarly, no deaths were reported among children or adolescents with SARS[16]. The molecular mechanism of mild symptoms in children may be related to angiotensin-converting enzyme II (ACE2). Already identified as the SARS-CoV receptor[20, 21], ACE2 has been shown to mediate SARS-CoV-2 infection of the type II alveolar cells [22-24]. Paradoxically, although ACE2 mediates viral entry to the host, its deficiency worsens lung injury in experimental models[25, 26]. Most important of all, there had been a significant age-specific decline of ACE2 expression in rat lung, especially during the later aging process[27], which may explain why pediatric patients with SARS or COVID-19 showed milder or no symptoms. 
In addition to respiratory droplet and direct contact transmission, COVID-19 has been proven to be transmitted through the fecal-oral route ${ }^{[30]}$ and ocular conjunctival route. Considering this, once exposed, children are very likely to be infected. Most if not all children patients have been in close contact with infected adults as a household contact, suggesting a "parent to child" transmission, which was believed to be the most important route of transmission that put children at particular risk. However, in our observations and some other reports[5, 6], no reverse transmission (such as"child to parent"transmission) has been identified even after long-term close contact with the siblings and elderly. Similarly and surprisingly, there had been no major spread of the disease among classmates in schools during the SARS epidemic in 2003-2004. However, whether or not the SARS-CoV-2 is not easily transmitted from children to other individuals needs to be confirmed in further investigation using a larger sample.

There is no known effective pharmaceutical agent for COVID-19, especially for children. Several potential drug candidates, including lopinavir/ritonavir (Kaletra ${ }^{\circledR}$ ), nucleoside analogs, neuraminidase inhibitors, remdesivir, umifenovir (arbidol), DNA synthesis inhibitors, chloroquine, and Chinese traditional medicine have been proposed [28, 29]. Interferon- $a 2 b$ nebulization and Lopinavir/litonavir have been recommended as treatments for children[17, 18, 30], however, the safety, efficacy, treatment course, and side effects remain unknown. It has been suggested that antiviral drugs should not be used routinely unless in critical cases and that the goals of treatment should be to alleviate symptoms and maintain the immune balance[31].

Children might be less likely to become infected or, if infected, may show milder symptoms, and either of these situations would account for underrepresentation in the confirmed case count[32]. Future serological studies will likely show much asymptomatic disease in children. There are limitations in this study, with few samples and short follow-up time, which limit the interpretation of more clinical significance.

\section{Conclusion}

Our retrospective study of 10 cases of children COVID-19 feeds into the ongoing efforts to understand COVID-19. Children's infection is mainly caused by family clusters. No transmission to other individuals from children was found in our observation. The clinical manifestations in children with COVID-19 are non-specific with milder symptoms and good outcomes.

\section{Abbreviations}

COVID-19: Coronavirus Disease 2019; SARS-CoV-2: Severe Acute Respiratory Syndrome Coronavirus 2; CT: Computed Tomograms; ICU: Intensive Care Unit; qRT-PCR: quantitative real-time polymerase chain reaction; CRP: C-reactive protein; ACE2: angiotensin-converting enzyme II.

\section{Declarations}

\section{Acknowledgments}

We thank all medical workers taking part in investigation and treatment of COVID-19 patients.

\section{Authors' contributions}

MC, PPF, RP, and DCZ conceptualized the study design. ZL, JHL, SWH, and WWW recruited the patients, collected specimens, collected demographic, clinical, and laboratory data; MC, PPF, RP, and DCZ analyzed the data; and MC, PPF, RP, and DCZ wrote the initial drafts of the manuscript; All authors read and approved the final manuscript.

\section{Funding}

Not applicable.

\section{Availability of data and materials}

All data needed to evaluate the conclusions in the paper are present in the paper.

\section{Ethics approval and consent to participate}

This study was approved by the Medical Ethical Committee of Zhongnan Hospital of Wuhan University (clinical ethical approval number 2020004). The written informed consent was waived for emerging infectious diseases.

\section{Consent for publication}

Not applicable.

\section{Competing interests}

The authors declare that they have no competing interests.

\section{References}

1. Wu F, Zhao S, Yu B, Chen Y, Wang W, Song Z, Hu Y, Tao Z, Tian J, Pei Y et al. A new coronavirus associated with human respiratory disease in China. NATURE 2020, 579; 2020: 265-269. 
2. DB J, CDC COVID- Response Team. Update: Public Health Response to the Coronavirus Disease 2019 Outbreak - United States, February 24, 2020. MMWR. Morbidity and mortality weekly report (MMWR Morb. Mortal. Wkly. Rep.) 2020, 69(8):216-219.

3. WHO. Coronavirus disease 2019 (COVID-19) Situation Report-50. 2020. https://www.who.int. Accessed 10 Mar 2020.

4. National Health Commission of People's Republic of China. Diagnosis and treatment of pneumonia caused by novel coronavirus (trial version 7). http://www.nhc.gov.cn. Accessed 4 Mar 2020.

5. Chen F, Liu ZS, Zhang FR, Xiong RH, Chen Y, Cheng XF, Wang WY, Ren J. [First case of severe childhood novel coronavirus pneumonia in China]. Zhonghua Er Ke Za Zhi 2020, 58(3):179-182.

6. Zhang YH, Lin DJ, Xiao MF, Wang JC, Wei Y, Lei ZX, Zeng ZQ, Li L, Li HA, Xiang W. [2019-novel coronavirus infection in a three-month-old baby]. Zhonghua Er Ke Za Zhi 2020, 58(0):E6.

7. Kam KQ, Yung CF, Cui L, Lin TPR, Mak TM, Maiwald M, Li J, Chong CY, Nadua K, Tan N et al. A Well Infant with Coronavirus Disease 2019 (COVID-19) with High Viral Load. CLIN INFECT DIS 2020.

8. Wang D, Ju XL, Xie F, Lu Y, Li FY, Huang HH, Fang XL, Li YJ, Wang JY, Yi B et al. [Clinical analysis of 31 cases of 2019 novel coronavirus infection in children from six provinces (autonomous region) of northern China]. Zhonghua Er Ke Za Zhi 2020, 58(4):E11.

9. Cai JH, Wang XS, Ge YL, Xia AM, Chang HL, Tian H, Zhu YX, Wang QR, Zeng JS. First case of 2019 novel coronavirus infection in children in Shanghai. Zhonghua Er Ke Za Zhi 2020, 58(2):86-87.

10. Xiong DX, Jiang JY, Feng Y, Xiao HZ, Yu J, Peng Z, Lang CH. Two cases of new coronavirus pneumonia in children. Chinese Pediatric Emergency Medicine 2020(00):E2.

11. Deng HL, Zhang YF, Wang Y, Li FY. Two cases of new coronavirus pneumonia in children. Chinese Pediatric Emergency Medicine 2020(00):E1.

12. Feng K, Yun YX, Wang XF, Yang GD, Zheng YJ, Lin CM, Wang LF. Analysis of CT features of 15 Children with 2019 novel coronavirus infection. Chinese Journal of Pediatrics 2020(00):E7.

13. Ma HJ, Shao JB, Wang YJ, Zhai AG, Zheng NN, Li Q, Liu Y. High-resolution CT findings of children with 2019 new coronavirus pneumonia. Chinese Journal of Radiology 2020(00):E2.

14. Chen N, Zhou M, Dong X, Qu J, Gong F, Han Y, Qiu Y, Wang J, Liu Y, Wei Y et al. Epidemiological and clinical characteristics of 99 cases of 2019 novel coronavirus pneumonia in Wuhan, China: a descriptive study. The Lancet 2020, 395(10223):507-513.

15. Guan W, Ni Z, Hu Y, Liang W, Ou C, He J, Liu L, Shan H, Lei C, Hui DSC et al. Clinical Characteristics of Coronavirus Disease 2019 in China. The New England journal of medicine 2020, 382(18):1708-1720.

16. Stockman LJ, Massoudi MS, Helfand R, Erdman D, Siwek AM, Anderson LJ, Parashar UD. Severe acute respiratory syndrome in children. Pediatr. Infect. Dis. J. 2007, 26(1):68-74.

17. Chen Z, Fu J, Shu Q, Chen Y, Hua C, Li F, Lin R, Tang L, Wang T, Wang W et al. Diagnosis and treatment recommendations for pediatric respiratory infection caused by the 2019 novel coronavirus. World J Pediatr 2020, 16(3):240-246.

18. Shen K, Yang Y, Wang T, Zhao D, Jiang Y, Jin R, Zheng Y, Xu B, Xie Z, Lin L et al. Diagnosis, treatment, and prevention of 2019 novel coronavirus infection in children: experts' consensus statement. World J Pediatr 2020, 16(3):223-231.

19. Li AM, Ng PC. Severe acute respiratory syndrome (SARS) in neonates and children. Arch. Dis. Child. Fetal Neonatal Ed. 2005, 90(6):F461-F465.

20. Kuba K, Imai Y, Rao S, Gao H, Guo F, Guan B, Huan Y, Yang P, Zhang Y, Deng W et al. A crucial role of angiotensin converting enzyme 2 (ACE2) in SARS coronavirus-induced lung injury. NAT MED 2005, 11(8):875-879.

21. Li W, Moore MJ, Vasilieva N, Sui J, Wong SK, Berne MA, Somasundaran M, Sullivan JL, Luzuriaga K, Greenough TC et al. Angiotensin-converting enzyme 2 is a functional receptor for the SARS coronavirus. NATURE 2003, 426(6965):450-454.

22. Chan JF, Kok K, Zhu Z, Chu H, To KK, Yuan S, Yuen K. Genomic characterization of the 2019 novel human-pathogenic coronavirus isolated from a patient with atypical pneumonia after visiting Wuhan. EMERG MICROBES INFEC 2020, 9(1):221-236.

23. Li R, Qiao S, Zhang G. Analysis of angiotensin-converting enzyme 2 (ACE2) from different species sheds some light on cross-species receptor usage of a novel coronavirus 2019-nCoV. In., vol. 80; 2020: 469-496.

24. Xu H, Zhong L, Deng J, Peng J, Dan H, Zeng X, Li T, Chen Q. High expression of ACE2 receptor of 2019-nCoV on the epithelial cells of oral mucosa. INT J ORAL SCI 2020, 12(1):8.

25. Wang J, Zhao S, Liu M, Zhao Z, Xu Y, Wang P, Lin M, Xu Y, Huang B, Zuo X et al. ACE2 expression by colonic epithelial cells is associated with viral infection, immunity and energy metabolism. medRxiv 2020:2020-2022.

26. Wu Y. Compensation of ACE2 Function for Possible Clinical Management of 2019-nCoV-Induced Acute Lung Injury. VIROL SIN 2020.

27. Xie X, Chen J, Wang X, Zhang F, Liu Y. Age- and gender-related difference of ACE2 expression in rat lung. LIFE SCI 2006, 78(19):2166-2171.

28. Lu H. Drug treatment options for the 2019-new coronavirus (2019-nCoV). BIOSCI TRENDS 2020, 14(1):69-71.

29. Wang M, Cao R, Zhang L, Yang X, Liu J, Xu M, Shi Z, Hu Z, Zhong W, Xiao G. Remdesivir and chloroquine effectively inhibit the recently emerged novel coronavirus (2019-nCoV) in vitro. In., vol. 30; 2020: 269-271.

30. Arabi YM, Alothman A, Balkhy HH, Al-Dawood A, AlJohani S, Al Harbi S, Kojan S, Al Jeraisy M, Deeb AM, Assiri AM et al. Treatment of Middle East Respiratory Syndrome with a combination of lopinavir-ritonavir and interferon- $\beta 1 \mathrm{~b}$ (MIRACLE trial): study protocol for a randomized controlled trial. In., vol. 19; 2018: 81.

31. Yang P, Liu P, Li D, Zhao D. Corona Virus Disease 2019, a growing threat to children? J Infect. 80; 2020: 671-693. 
32. Li Q, Guan X, Wu P, Wang X, Zhou L, Tong Y, Ren R, Leung KSM, Lau EHY, Wong JY et al. Early Transmission Dynamics in Wuhan, China, of Novel Coronavirus-Infected Pneumonia. N. Engl. J. Med. 2020 , 382(13):1199-1207.

\section{Tables}

Table 1. Demographics, baseline characteristics and epidemiological history of 10 hospitalized children with COVID-19

\begin{tabular}{|c|c|c|c|c|c|c|c|c|c|}
\hline & Patients & & & & & & & & \\
\hline Characteristic & 1 & 2 & 3 & 4 & 5 & 6 & 7 & 8 & 9 \\
\hline \multicolumn{10}{|l|}{ Demographics } \\
\hline Age & 8 & 9 & 7 & 11 & 14 & 3 & 2 & 7 & 15 \\
\hline Sex & Female & Male & Female & Male & Female & Male & Male & Female & Male \\
\hline \multicolumn{10}{|l|}{$\begin{array}{l}\text { Epidemiologic } \\
\text { history }\end{array}$} \\
\hline $\begin{array}{l}\text { No. of family } \\
\text { members } \\
\text { infected }\end{array}$ & 2 & 2 & 2 & 2 & 1 & 1 & 0 & 0 & 0 \\
\hline $\begin{array}{l}\text { Linkage to } \\
\text { Wuhan }\end{array}$ & No & No & No & No & No & No & Yes & Yes & No \\
\hline \multicolumn{10}{|l|}{$\begin{array}{l}\text { Clinical } \\
\text { manifestation }\end{array}$} \\
\hline $\begin{array}{l}\text { Symptoms } \\
\text { and signs }\end{array}$ & Fever,cough & Fever & None & None & None & None & Cough & $\begin{array}{l}\text { Fever,cough, } \\
\text { expectoration }\end{array}$ & Cough \\
\hline $\begin{array}{l}\text { Severe } \\
\text { complications }\end{array}$ & None & None & None & None & None & None & None & None & None \\
\hline \multicolumn{10}{|l|}{$\begin{array}{l}\text { Treatment and } \\
\text { prognosis }\end{array}$} \\
\hline $\begin{array}{l}\text { Duration of } \\
\text { hospitalization }\end{array}$ & 22 & 17 & 14 & 19 & 21 & 16 & 12 & 7 & 26 \\
\hline $\begin{array}{l}\text { Intensive unit } \\
\text { care }\end{array}$ & No & No & No & No & No & No & No & No & No \\
\hline $\begin{array}{l}\text { Oxygen } \\
\text { therapy }\end{array}$ & Non-invasive & None & None & None & None & None & None & None & None \\
\hline Antiviral drugs & Lopinavir/Ritonavir & Lopinavir/Ritonavir & Arbidol & Arbidol & Arbidol & Oseltamivir & Oseltamivir & $\begin{array}{l}\text { Lopinavir/ } \\
\text { Ritonavir }\end{array}$ & Lopinavir/Ritc \\
\hline Antibiotic & None & None & None & None & None & None & None & None & None \\
\hline $\begin{array}{l}\text { Traditional } \\
\text { Chinese } \\
\text { medicine }\end{array}$ & Yes & Yes & None & Yes & Yes & None & None & Yes & Yes \\
\hline
\end{tabular}

Table 2. Laboratory results and radiologic findings of 10 hospitalized children with COVID-19 


\begin{tabular}{|c|c|c|c|c|c|c|c|c|c|c|}
\hline & Patients & & & & & & & & & \\
\hline Parameter & 1 & 2 & 3 & 4 & 5 & 6 & 7 & 8 & 9 & 10 \\
\hline \multicolumn{11}{|l|}{ Blood routine } \\
\hline Neutrophils (\%) & 53 & 60 & 44.1】 & 43.7\ & $38.2 \downarrow$ & 54.2 & 65.6 & 50.7 & $38.6 \downarrow$ & 55.1 \\
\hline Neutrophils $\left(\times 10^{9} / \mathrm{L}\right)$ & $3.35 \downarrow$ & $2.32 \downarrow$ & $4.15 \downarrow$ & 5.4 & 7.74 & 6.84 & 7.19 & 5.36 & $4.97 \downarrow$ & 5.2 \\
\hline Lymphocytes(\%) & 32.7 & 32 & $41.7 \uparrow$ & 37 & $52.6 \uparrow$ & 31.5 & 19.2 & 37.4 & $47.1 \uparrow$ & 30.1 \\
\hline Lymphocytes $\left(\times 10^{9} / \mathrm{L}\right)$ & 1.78 & 1.39 & 1.83 & 2.36 & 2.96 & $3.71 \uparrow$ & $4.72 \uparrow$ & 2.27 & 1.92 & 2.9: \\
\hline \multicolumn{11}{|l|}{ Infectious biomarkers } \\
\hline $\begin{array}{l}\text { C-reactive protein } \\
\text { \mg/L】 }\end{array}$ & 4.49 & 5 & 3 & 4 & 3 & 3 & $5.5 \uparrow$ & 3.5 & 3.5 & 33. \\
\hline Procalcitonin $\rrbracket \mathrm{ng} / \mathrm{mL} \rrbracket$ & 0.02 & 0.03 & 0.04 & 0.03 & 0.02 & 0.03 & 0.03 & 0.04 & 0.03 & $0.0 !$ \\
\hline \multicolumn{11}{|l|}{ Nucleic acid tests } \\
\hline $\begin{array}{l}\text { Positive times/ Total } \\
\text { Times }\end{array}$ & $4 / 6$ & $3 / 5$ & $4 / 6$ & $5 / 7$ & $4 / 6$ & $5 / 7$ & $2 / 4$ & $1 / 3$ & $4 / 6$ & $1 / 3$ \\
\hline $\begin{array}{l}\text { Negative conversion } \\
\text { days }\end{array}$ & 20 & 16 & 10 & 18 & 21 & 16 & 7 & 5 & 22 & 6 \\
\hline \multicolumn{11}{|l|}{ CT imaging } \\
\hline On admission & $\begin{array}{l}\text { Single high } \\
\text { density } \\
\text { shadow }\end{array}$ & $\begin{array}{l}\text { Single } \\
\text { high } \\
\text { density } \\
\text { shadow }\end{array}$ & Normal & $\begin{array}{l}\text { Single high } \\
\text { density } \\
\text { shadow }\end{array}$ & $\begin{array}{l}\text { Ground- } \\
\text { glass } \\
\text { opacity }\end{array}$ & Normal & $\begin{array}{l}\text { Multiple high } \\
\text { density } \\
\text { shadow }\end{array}$ & $\begin{array}{l}\text { Multiple } \\
\text { high density } \\
\text { shadow }\end{array}$ & $\begin{array}{l}\text { Ground- } \\
\text { glass } \\
\text { opacity }\end{array}$ & $\begin{array}{l}\text { Gro } \\
\text { opa } \\
\text { con }\end{array}$ \\
\hline Before discharge & Improvement & Normal & Normal & Improvement & Improvement & Normal & Improvement & Improvement & Normal & $\operatorname{Imp}$ \\
\hline
\end{tabular}

\section{Figures}

Admission

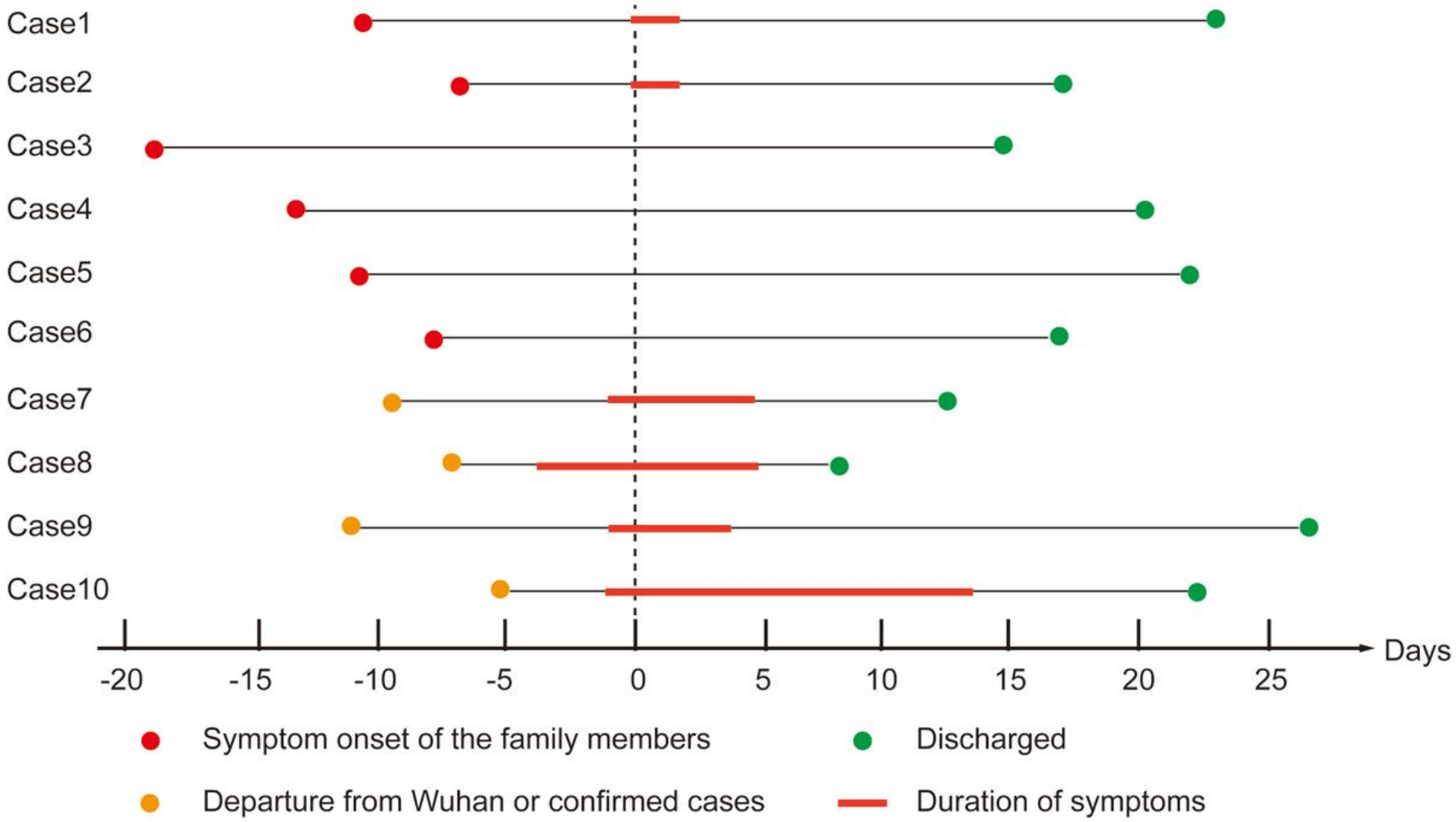

Figure 1 
Timeline of the 10 cases before and after the onset of illness. For each patient, the day of admission is set as day0, the incubation period, duration of symptoms and hospitalization are shown in the figure. The red dots indicate the time when the first confirmed COVID-19 in the family developed symptoms. The yellow dots indicate the time when the child ended his or her separate tour or residence history in Wuhan or cities with confirmed cases. The green dots indicate when the child was discharged. The red line represents the duration of the symptoms.

\section{Admission}

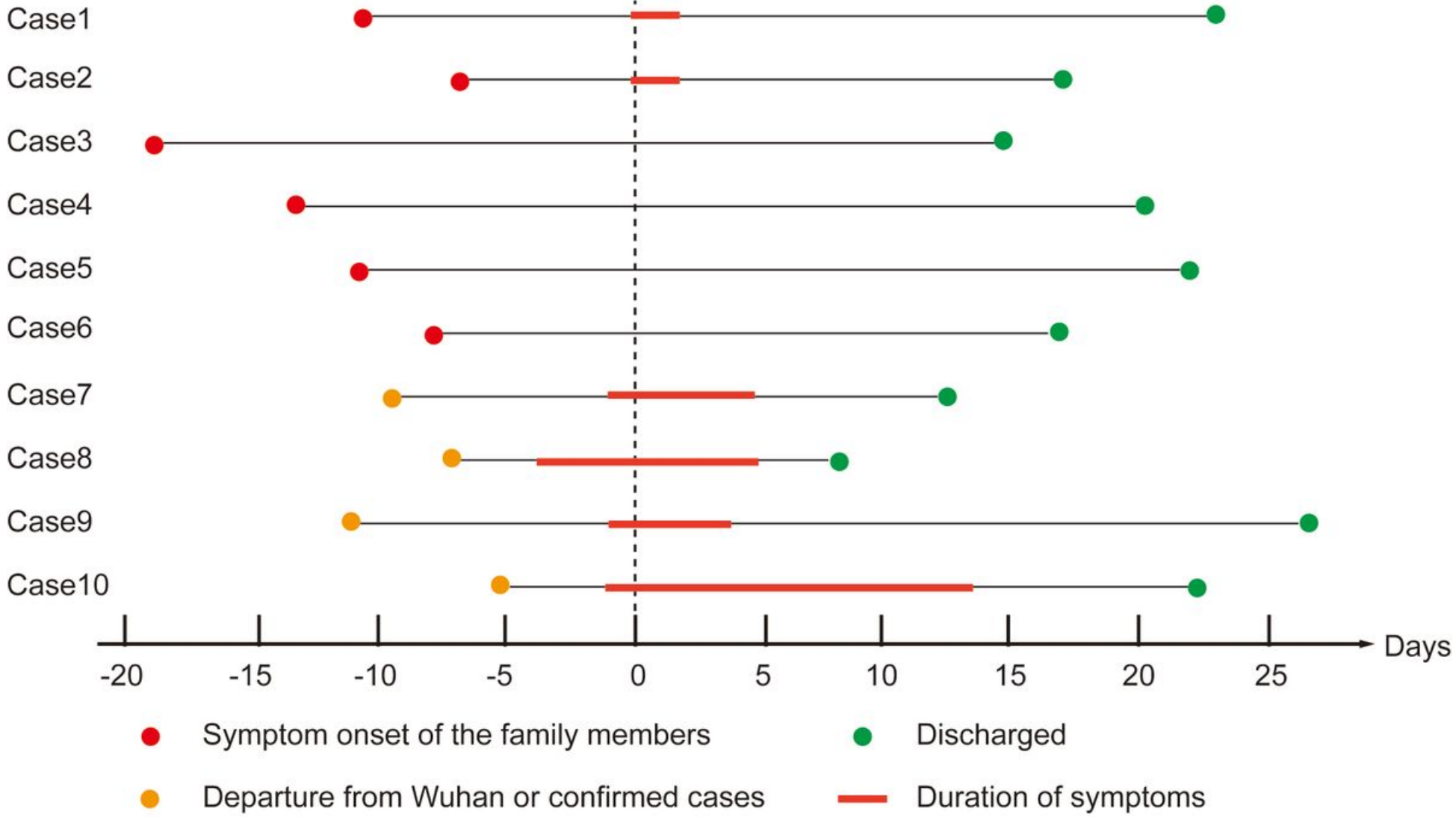

Figure 1

Timeline of the 10 cases before and after the onset of illness. For each patient, the day of admission is set as day0, the incubation period, duration of symptoms and hospitalization are shown in the figure. The red dots indicate the time when the first confirmed COVID-19 in the family developed symptoms. The yellow dots indicate the time when the child ended his or her separate tour or residence history in Wuhan or cities with confirmed cases. The green dots indicate when the child was discharged. The red line represents the duration of the symptoms. 
Admission

Case1

Case2

Case3

Case4

Case5

Case6

Case7

Case8

Case9

Case10

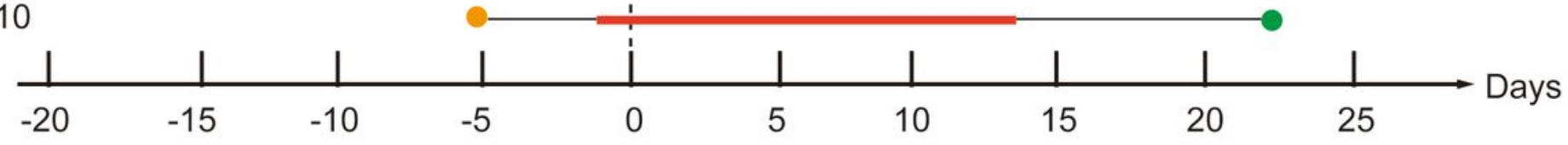

- Symptom onset of the family members

- Discharged

- Departure from Wuhan or confirmed cases

\section{Duration of symptoms}

\section{Figure 1}

Timeline of the 10 cases before and after the onset of illness. For each patient, the day of admission is set as day0, the incubation period, duration of symptoms and hospitalization are shown in the figure. The red dots indicate the time when the first confirmed COVID-19 in the family developed symptoms. The yellow dots indicate the time when the child ended his or her separate tour or residence history in Wuhan or cities with confirmed cases. The green dots indicate when the child was discharged. The red line represents the duration of the symptoms. 


\section{Case 1}
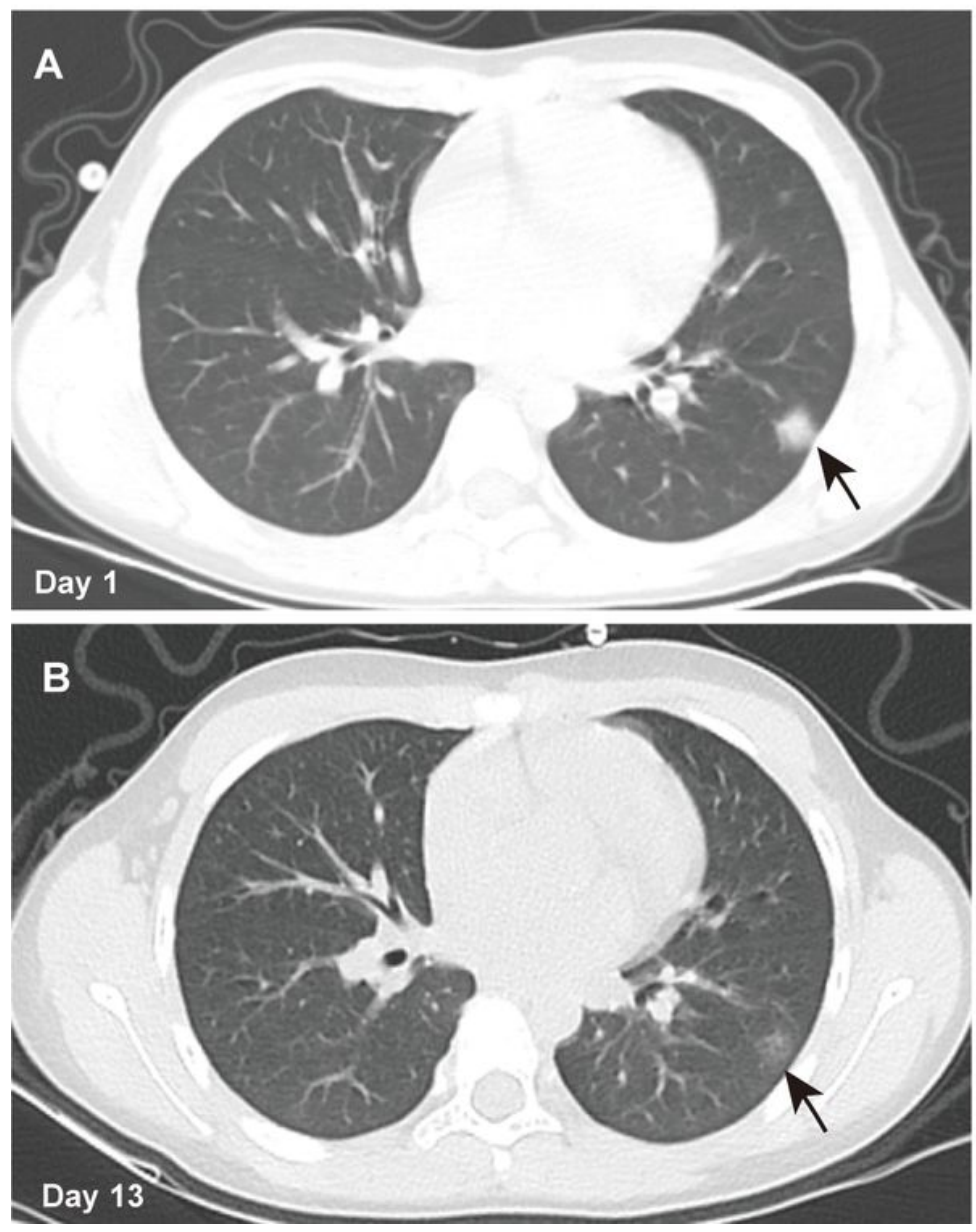

Case 10
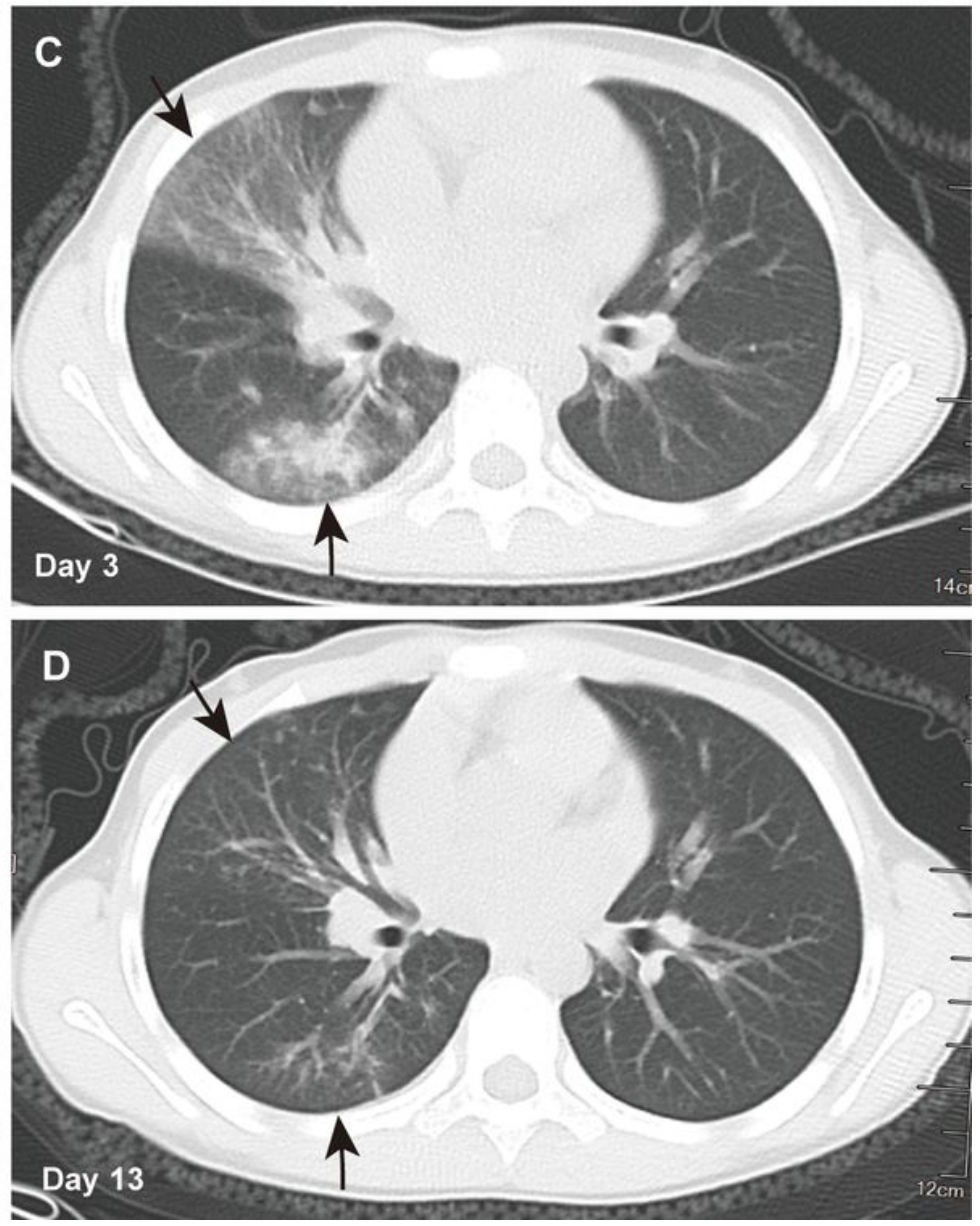

Figure 2

Transverse chest CT from two patients. Case1: an 8 years old girl. A showed a single localized high-density shadow of the left lower lobe near the pleura on day 1 after symptom (fever) onset. B showed great improvement 12 days later before discharge. Case10: a 7 years old girl. C showed ground-glass opacity with consolidation of right middle and lower lobes at admission 3 days after symptom (cough and fever) onset. D showed great improvement 10 days later before discharge. 


\section{Case 1}
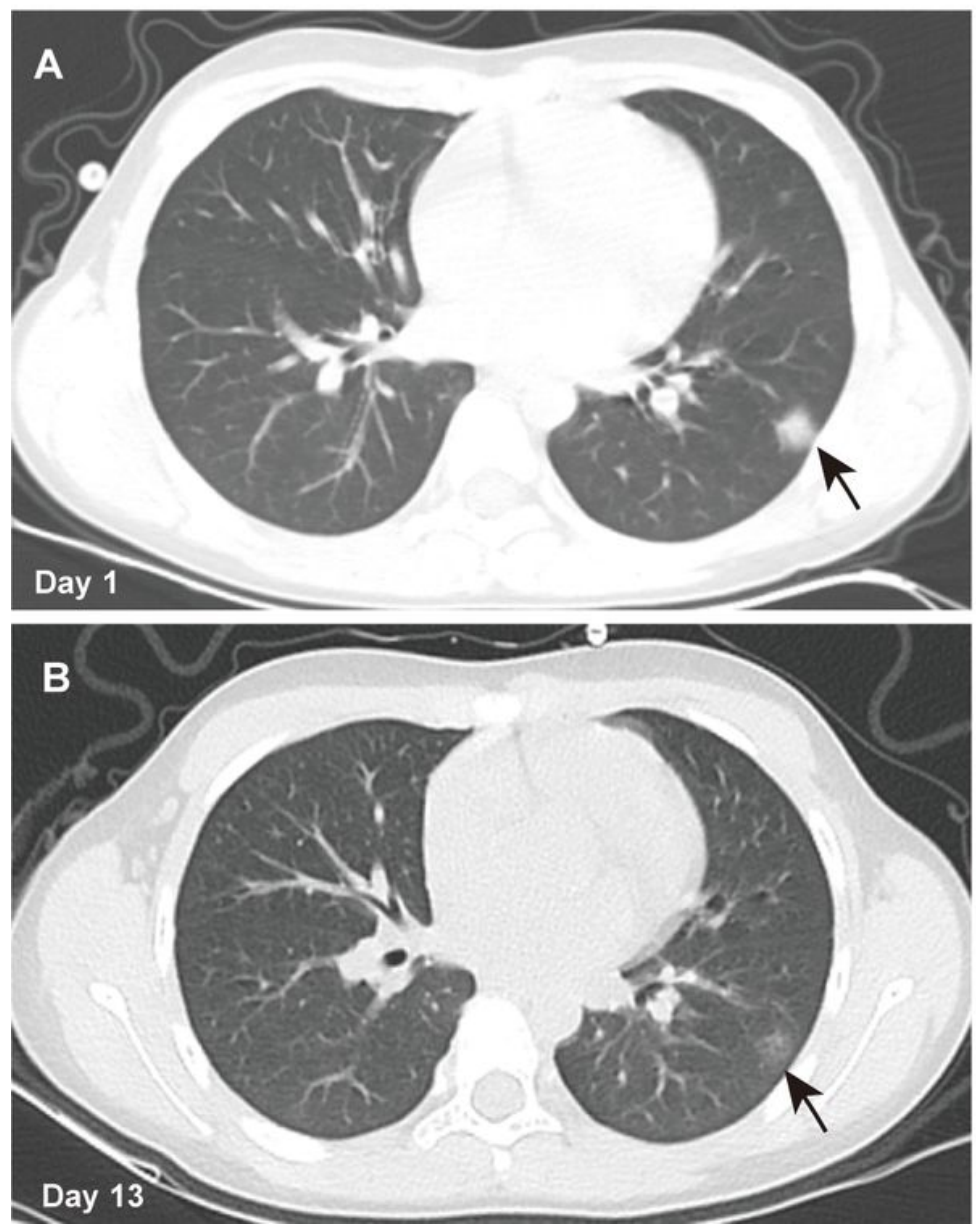

Case 10
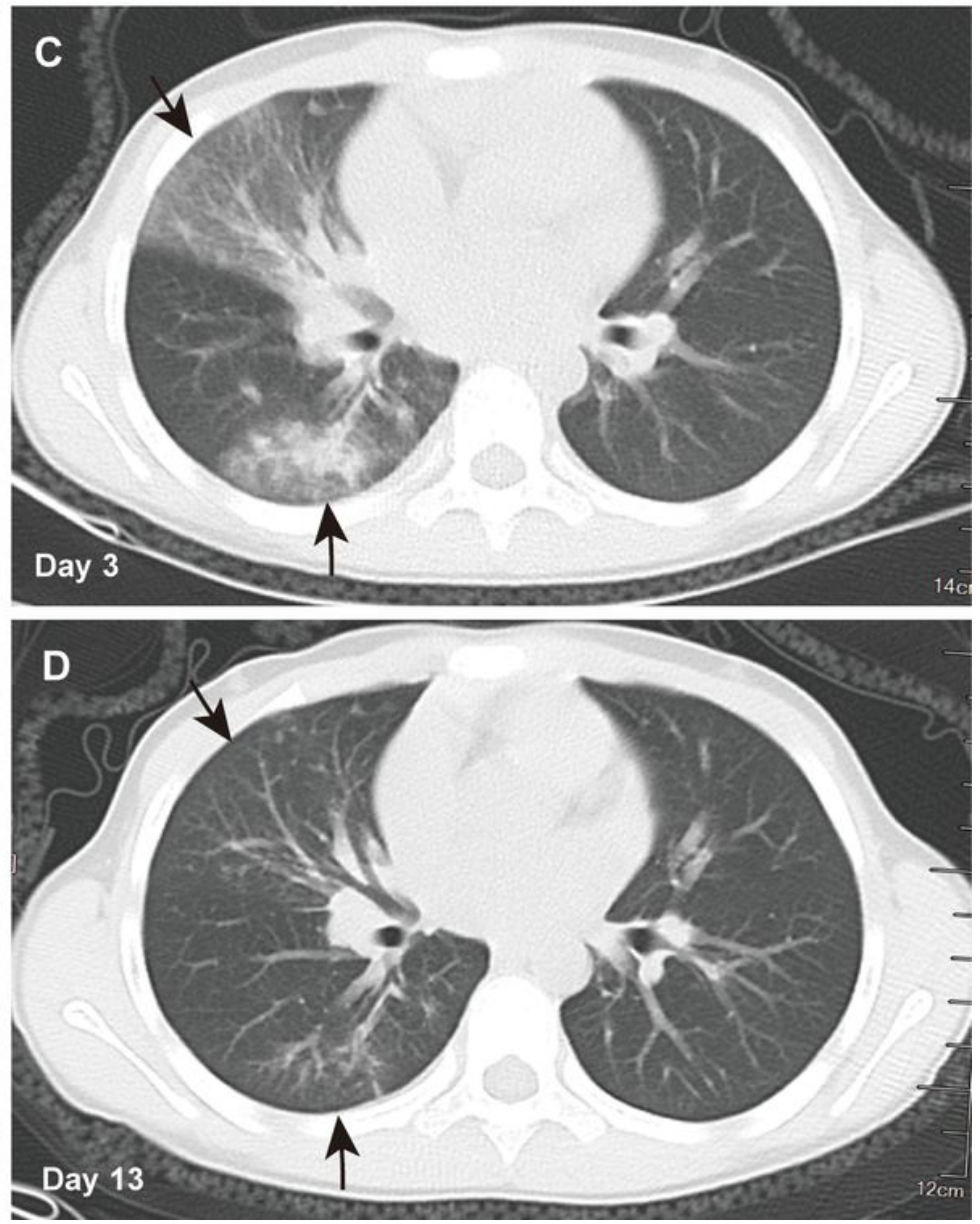

Figure 2

Transverse chest CT from two patients. Case1: an 8 years old girl. A showed a single localized high-density shadow of the left lower lobe near the pleura on day 1 after symptom (fever) onset. B showed great improvement 12 days later before discharge. Case10: a 7 years old girl. C showed ground-glass opacity with consolidation of right middle and lower lobes at admission 3 days after symptom (cough and fever) onset. D showed great improvement 10 days later before discharge. 


\section{Case 1}
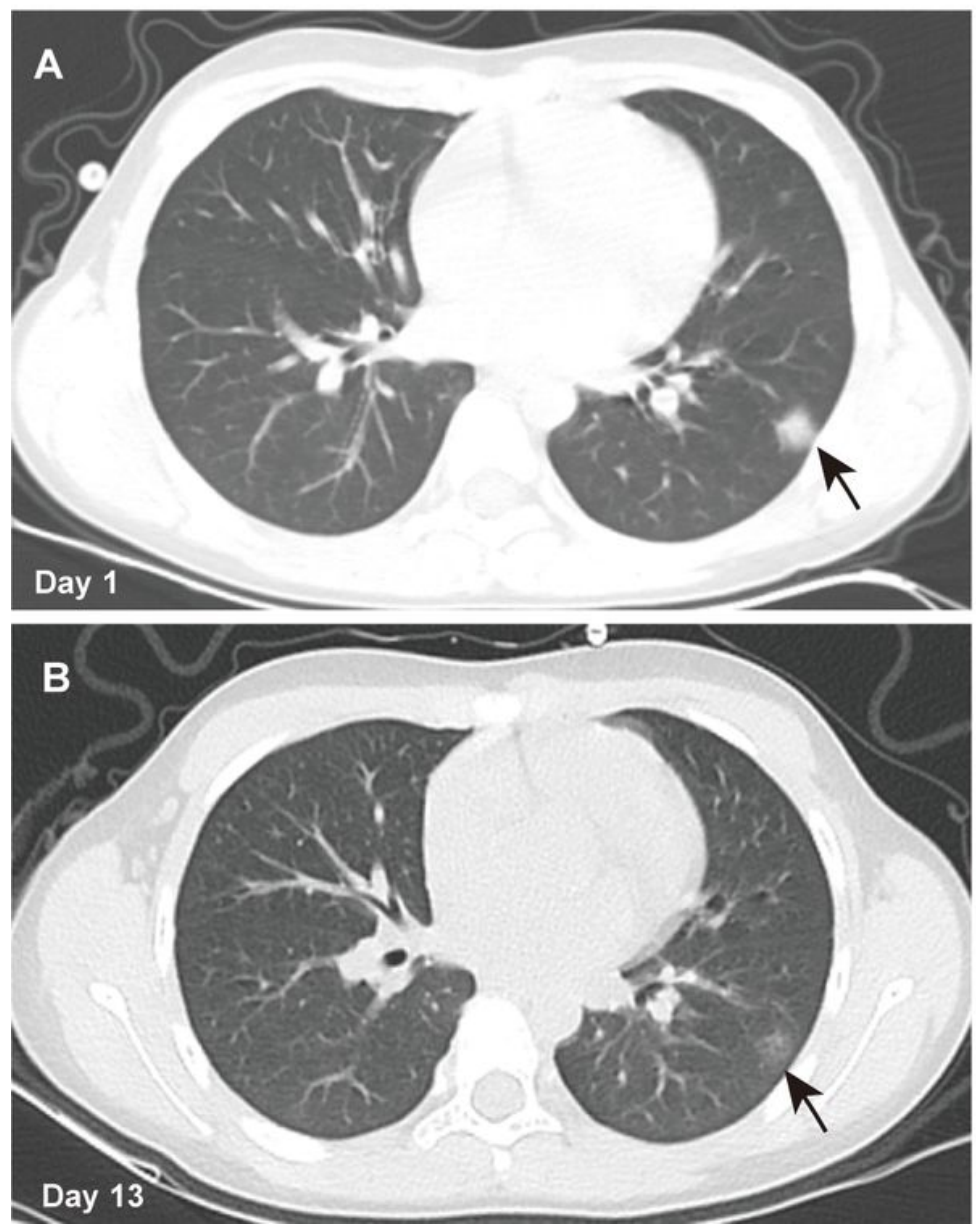

Case 10
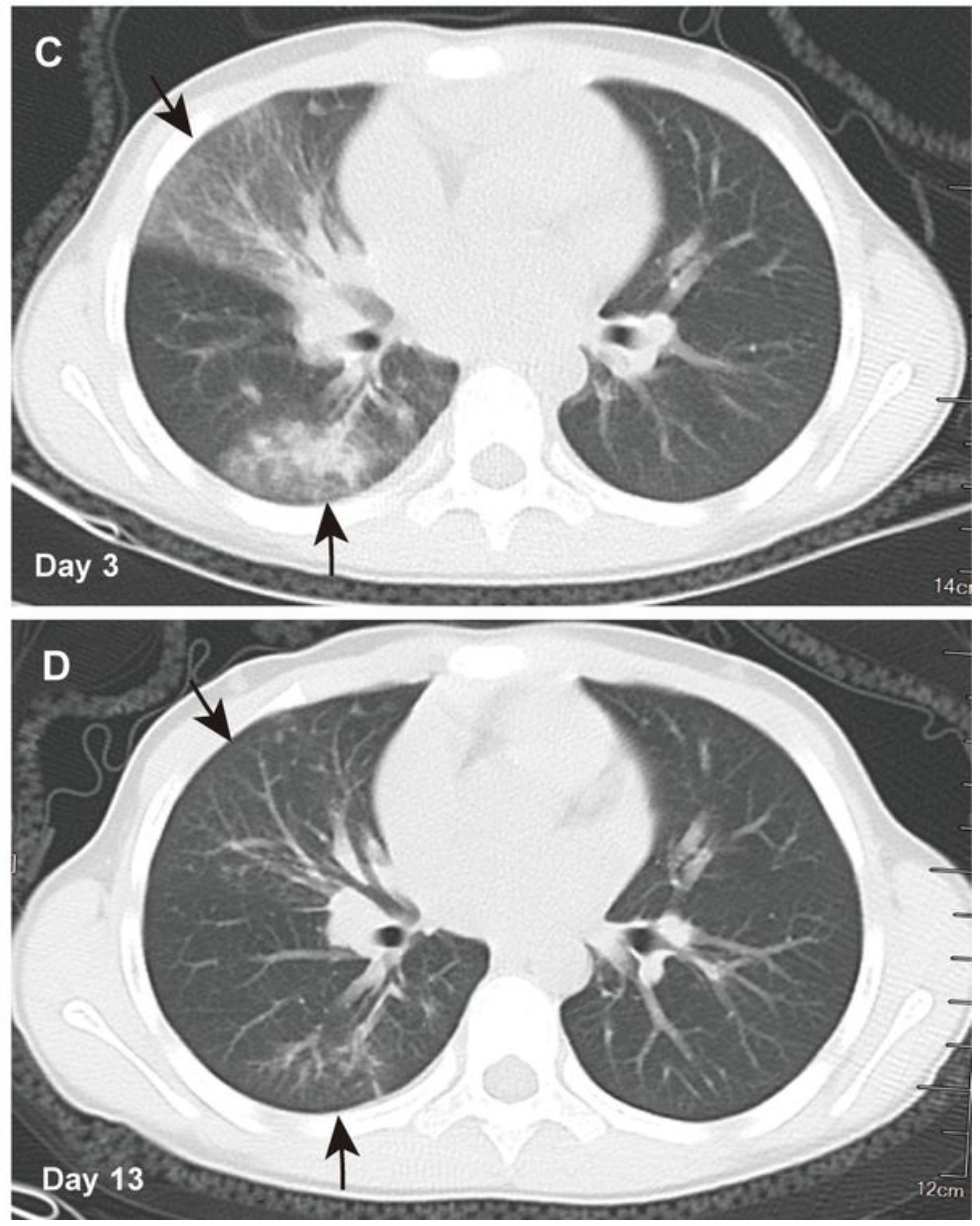

Figure 2

Transverse chest CT from two patients. Case1: an 8 years old girl. A showed a single localized high-density shadow of the left lower lobe near the pleura on day 1 after symptom (fever) onset. B showed great improvement 12 days later before discharge. Case10: a 7 years old girl. C showed ground-glass opacity with consolidation of right middle and lower lobes at admission 3 days after symptom (cough and fever) onset. D showed great improvement 10 days later before discharge. 